A PERFORMANCE COMPARISON BETWEEN AIR AND LIQUID RESIDENTIAL SOLAR HEATING SYSTEMS

By

S. Karaki

W. S. Duff

G. O. G. Löf

January 1978

Work Performed Under Contract No. EY-76-S-02-2868

Solar Energy Applications Laboratory

Colorado State University

Fort Collins, Colorado 


\section{DISCLAIMER}

This report was prepared as an account of work sponsored by an agency of the United States Government. Neither the United States Government nor any agency Thereof, nor any of their employees, makes any warranty, express or implied, or assumes any legal liability or responsibility for the accuracy, completeness, or usefulness of any information, apparatus, product, or process disclosed, or represents that its use would not infringe privately owned rights. Reference herein to any specific commercial product, process, or service by trade name, trademark, manufacturer, or otherwise does not necessarily constitute or imply its endorsement, recommendation, or favoring by the United States Government or any agency thereof. The views and opinions of authors expressed herein do not necessarily state or reflect those of the United States Government or any agency thereof. 


\section{DISCLAIMER}

Portions of this document may be illegible in electronic image products. Images are produced from the best available original document. 


\section{NOTICE}

This report was prepared as an account of work sponsored by the United States Government. Neither the United States nor the United States Department of Energy, nor any of their employees, nor any of their contractors, subcontractors, or their employees, makes any warranty, express or implied, or assumes any legal liability or responsibility for the accuracy, completeness or usefulness of any information, apparatus, product or process disclosed, or represents that its use would not infringe privately owned rights.

This report has been reproduced directly from the best available copy.

Available from the National Technical Information Service, U. S. Department of Commerce, Springfield, Virginia 22161.

Price: Paper Copy $\$ 4.00$

Microfiche $\$ 3 \cap \cap$ 


\title{
A PERFORMANCE COMPARISON BETWEEN AIR AND LIQUID \\ RESIDENTIAL SOLAR HEATING SYSTEMS
}

\author{
S. Karaki \\ W. S. Duff \\ G. 0. G. Löf
}

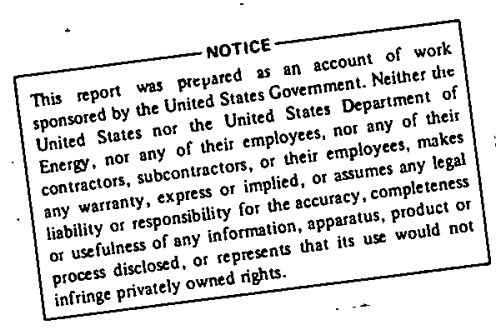

\section{Solar Energy Applications Laboratory \\ Colorado State University \\ Fort Collins, Colorado 80523}

\author{
Prepared for \\ U. S. Department of Energy \\ Washington, D.C. 20545 \\ and \\ National Training Fund \\ Sheet Metal and Air Conditioning Industry \\ Washington, D.C. 20036
}

January 1978 


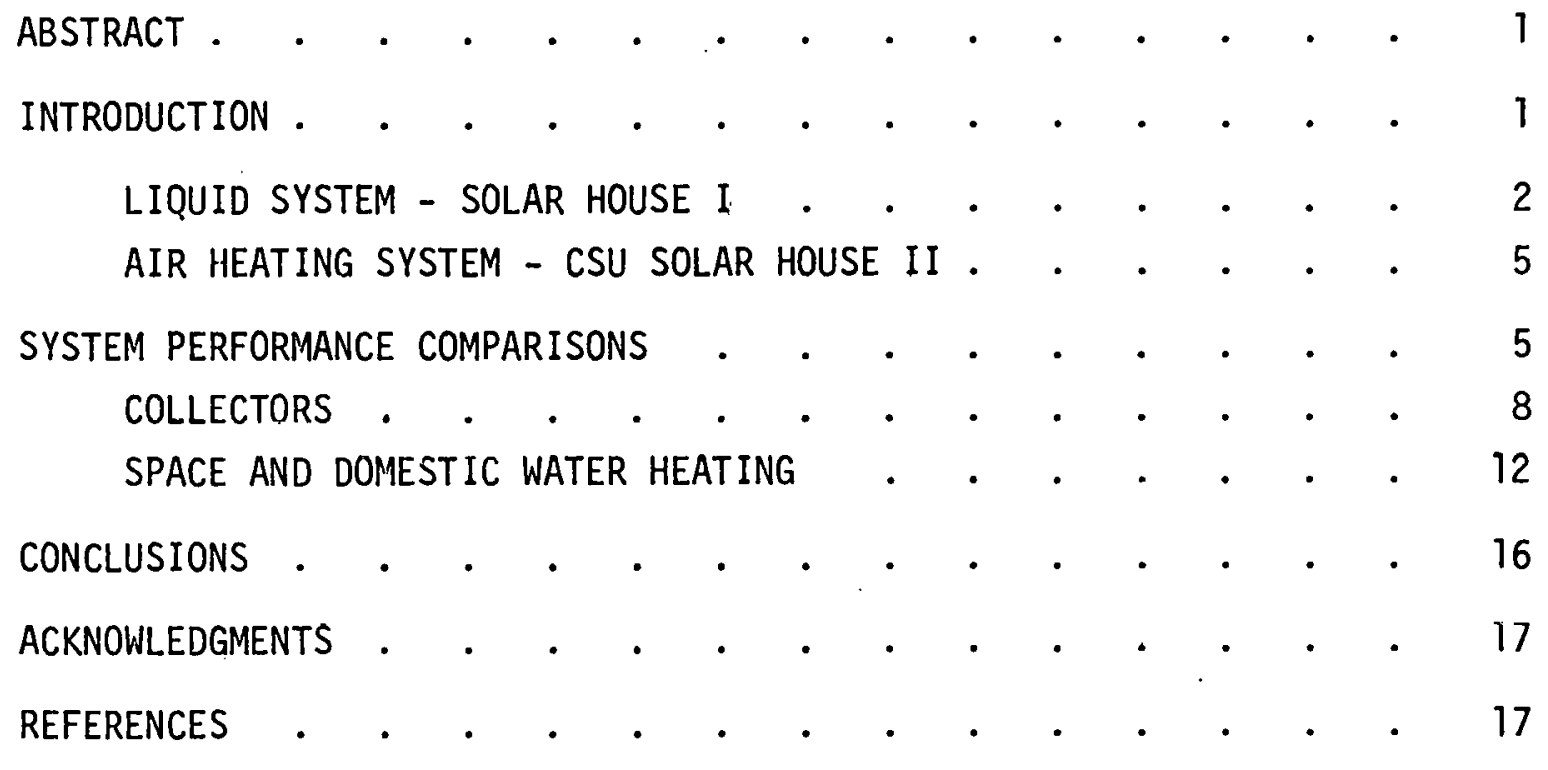

LIST OF FIGURES

Figure 1. Schematic of the Liquid Solar System in

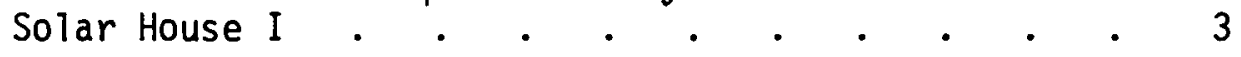

Figure 2. Schematic of the Air Solar System in Solar House II . 6

Figure 3. Comparative Performance of Collectors Operating with Systems (Based on same days) . . . . . . 10

Figure 4. Comparison of Solar Contributions to Total Load (Based on same days)

Figure 5. Comparison of Solar Contributions to Space Heating Load (Based on same days) $. . . \cdot . \cdot . \cdot 14$

Figure 6. Comparison of Solar Contributions to DHW Load (Based on same days) . . . . . . . . 15

\section{LIST OF TABLES}

Table 1. Thermal Performance Data for Solar House I . . . 7

Table 2. Thermal Performance Data for Solar House II . . . 9 
Zero Zero Zero Zero Nine RCD $\mathrm{SB} 0228 \cdot \mathrm{FO} 1$ 00009

R

(C00/2868--4) Performance comparison between air and 1 iquid residential solar heating systems.

Karaki, S.: Duff, W.S.; Loef, G.0.G. (Colorado State Univ., Fort Collins (USA). Solar Energy Applications

Lab.). Jan 1978. Contract E,Y-76-S-02-2868.

Unli mi ted.

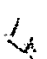

PNT-59

p

TIC

FILE- SB0228.FO1

$00009 R \quad S B 022878$ o3Uncl

orkaraki, S.; Duff, W.S.; Loef, G.0.G.

11 Performance comparison between air and liquid rasidential solar heating systems

$15 \mathrm{COO} / 2868-4$

24 Contract EY-76-S-02-2868

$37 \mathrm{Jan} 1978 \quad{ }_{3}$ Unlimited

50 Sol ar Energy

51 PNT-59 $52 \mathrm{P} \quad 5{ }_{3} \mathrm{RCO}$

55 TIC 56 United States of America (USA) 5 (United States of America (USA)

70950 $1143 \quad 71$ Colorado State Unive, Fort Collins (USA). Solar Energy Applications Lab.

Check DE: 43 AUTHORITY CHECK[Unlimited]. 
COMPARATIVE PERFORMANCE OF SOLAR SYSTEMS

IN CSU SOLAR HOUSES I AND II

\section{ABSTRACT}

Comparisons of system performance for the flat plate liquid-heating system in CSU Solar House I, the evacuated-tube collector system in Solar House I, and the flat plate air-heating system in CSU Solar House II are described for selected months of the 1976 and 1977 heating seasons. Only space and domestic water heating data are compared. The flat plate airand liquid-heating collectors operating with complete heating systems have nearly equal efficiencies when based upon solar flux while the collector fluids are flowing, but approximately 40 percent more energy is collected during a heating season with the air-heating system because the air system operates over a longer period of the day. On the basis of short-term data, the evacuated tube collector array on Solar House I is about 27 percent more efficient than the flat plate air-heating collector array on Solar House II based on gross roof area occupied by the collectors and manifolds.

\section{INTRODUCTION}

Solar House I and Solar House II in the Solar Village at Colorado State University are nearly identical buildings located approximately 100 feet apart. Both buildings are residential size with about $130 \mathrm{~m}^{2}$ $\left(1400 \mathrm{ft}^{2}\right)$ of floor space on the first floor and equal area in the basement. Both floors are heated and cooled. The south wall of the basement is above grade while the north wall is below grade. Collectors are mounted on the roof tilted at 45 degrees from horizontal and oriented southward, the storage and mechanical equipment for heating and air conditioning are located in the basements. The buildings are used for 
offices for the staff and graduate students of the Solar Energy Applications Laboratory and are occupied virtually everyday of the year.

A full complement of instruments are provided for each house to monitor the performances of the solar systems. In this report, the performance of the systems in the two houses are compared for selected months in 1976 and 1977, using data for the same days with the exception of March 1976. There were only 4.5 days of data available from Solar House I for that month which is not sufficient to represent the entire month.

\section{LIQUID SYSTEM - SOLAR HOUSE I}

The solar heating and cooling system in CSU Solar House I was completed in July 1974 and has been in operation since August 1974. Details for the design of the solar system in Solar House I and performance information for the period September 1974 through August 1975, have been reported previously $[1,2]$.

The solar heating and cooling system is shown schematically in Figure 1 and consists of flat-plate, liquid-heating collectors, water storage, lithium-bromide absorption air conditioners, and gas-fired auxiliary water boiler. The collectors were site built and occupy an overall roof area of $71.3 \mathrm{~m}^{2}\left(768 \mathrm{ft}^{2}\right)$ with an absorber area of $67.0 \mathrm{~m}^{2}$ $\left(721 \mathrm{ft}^{2}\right)$. The storage tank has a water volume of 4275 liters (1125 gallons). Although not shown in Figure 1, there is a domestic water heating system consisting of a 300-liter (80-gallon) preheater tank and a 150-1iter (40-gallon) conventional gas-fired hot water tank. A 50 percent solution of ethylene glycol and water flows through the collectors and is separated from the storage tank fluid with a counterflow heat exchanger. 


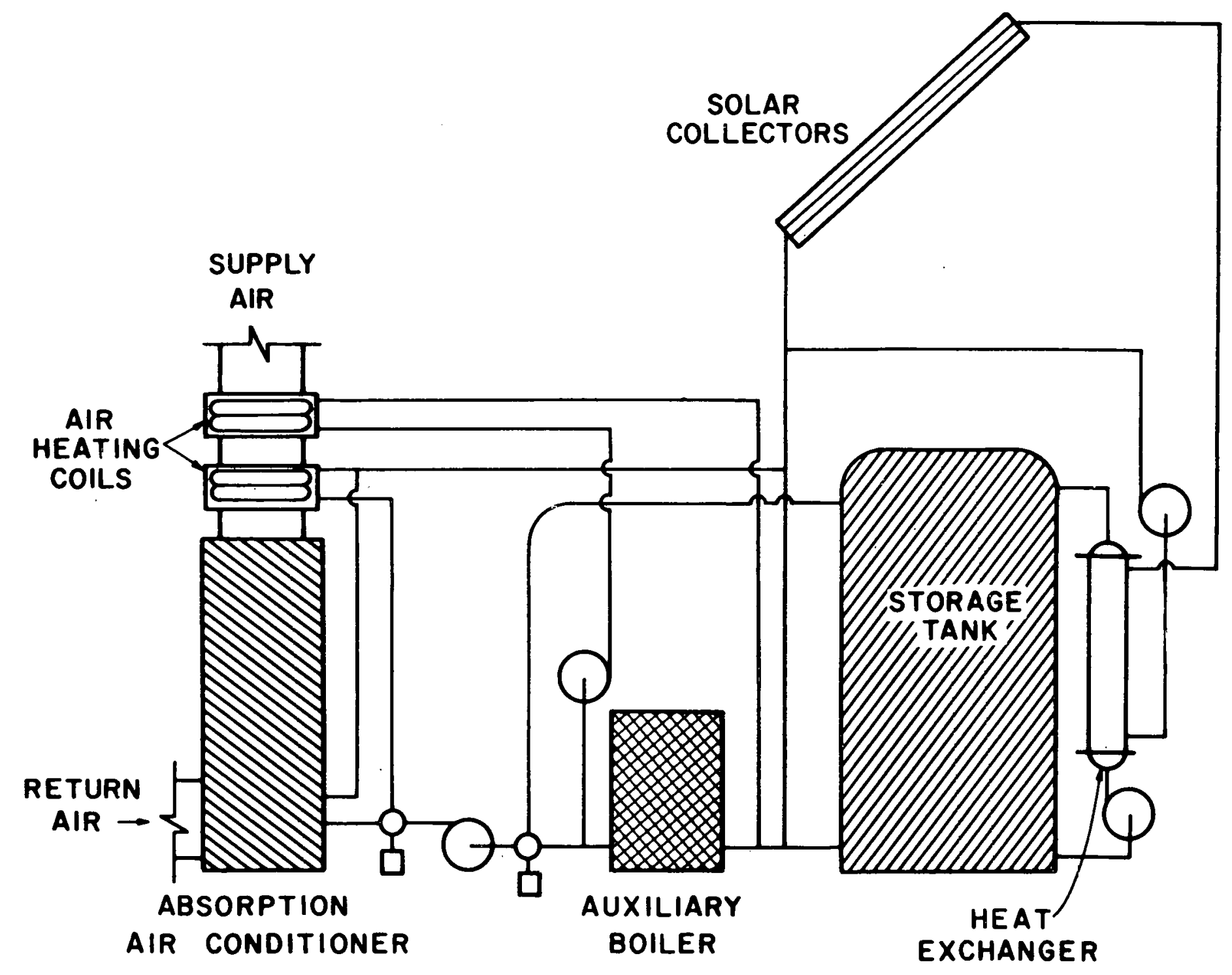

Figure 1. Schematic of the Liquid Solar System in Solar House I 
During November and December 1976, an additional set of evacuated tube collectors (made by Corning Glass Works) was mounted on a test bed located directly to the south of the Solar House. The set of collectors on the test bed consists of 36 modules and each module has six evacuated tubes, with a cumulative absorber area of $1.11 \mathrm{~m}^{2}\left(11.9 \mathrm{ft}^{2}\right)$, that covers a mounting area of $1.92 \mathrm{~m}^{2}\left(20.6 \mathrm{ft}^{2}\right)$. When mounted on the test bed, the gross area required for collectors and manifolds is $75.2 \mathrm{~m}^{2}$ $\left(807 \mathrm{ft}^{2}\right.$ ) although the total absorber area is $39.9 \mathrm{~m}^{2}$. There is a separate storage tank with 4275 liters (1125 gallons) of capacity for the evacuated tube collector system.

Both the flat plate collectors on the building roof and the evacuated tube system can deliver heat to the same space and domestic hot water loads in House I. Provision is therefore made to reject all of the heat collected from the roof-mounted collectors after the heat is delivered to the storage tank in the basement, and the heat from the evacuated tube collectors is utilized in the house. A data acquisition system and realtime analyses of heat flows are made and an equal amount of heat can be rejected from the flat plate system.

The provision for heat rejection was not utilized during the months for which the comparisons are made in this report because shortly after installation of the collectors on the test bed was completed in December 1976, the flat-plate collectors on the house became inoperative. The flat-plate collectors have since been repaired, but not in time for the 1976-1977 heating season. The data presented for Solar House I in 1976 are from the flat-plate collector system and the data for 1977 are from the evacuated tube system. 


\section{AIR HEATING SYSTEM - CSU SOLAR. HOUSE II}

The solar heating and nocturnal cooling air system in CSU Solar House II was completed in November 1975, and data collection began on 1 February 1976. Design details and descriptions of system operation are described in Reference [3] and a complete physical description of the system along with tabulated data on performance are provided in Reference [4]. The collectors in the system, shown schematically in Figure 2, are site-built and occupy an overall roof area of $68.4 \mathrm{~m}^{2}$ $\left(736 \mathrm{ft}^{2}\right)$ with $64.1 \mathrm{~m}^{2}\left(690 \mathrm{ft}^{2}\right)$. net collector area. The storage consists of $10.2 \mathrm{~m}^{3}\left(363 \mathrm{ft}^{3}\right)$ of pebbles with 1.9 to $3.8 \mathrm{~cm}$ size $(0.75$ to 1.5 inch in the short dimension), and a gas-fired auxiliary duct furnace is connected to the heat distribution system of the house.

Domestic water preheating is accomplished by an air-to-water heat exchanger with storage in a 300-liter (80-gallon) tank. The hot water heater is gas-fired with a capacity of 150 liters (40 gallons) and is limited in temperature to $60^{\circ} \mathrm{C}\left(140^{\circ} \mathrm{F}\right)$.

The system is operated by a single blower during the heating season with two sets of three motorized dampers to direct heat from the collectors to the house or to storage, and from storage to the house. A second blower is used in the summer to preheat water while the main blower circulates cool air from the evaporative cooler to storage and from storage to the conditioned space.

\section{SYSTEM PERFORMANCE COMPARISONS}

The thermal performance data for the site-built flat-plate system (SBFP) in Solar House I are presented in Table 1 for the period February to May 1976, and November through 10 December 1976. Several days are 


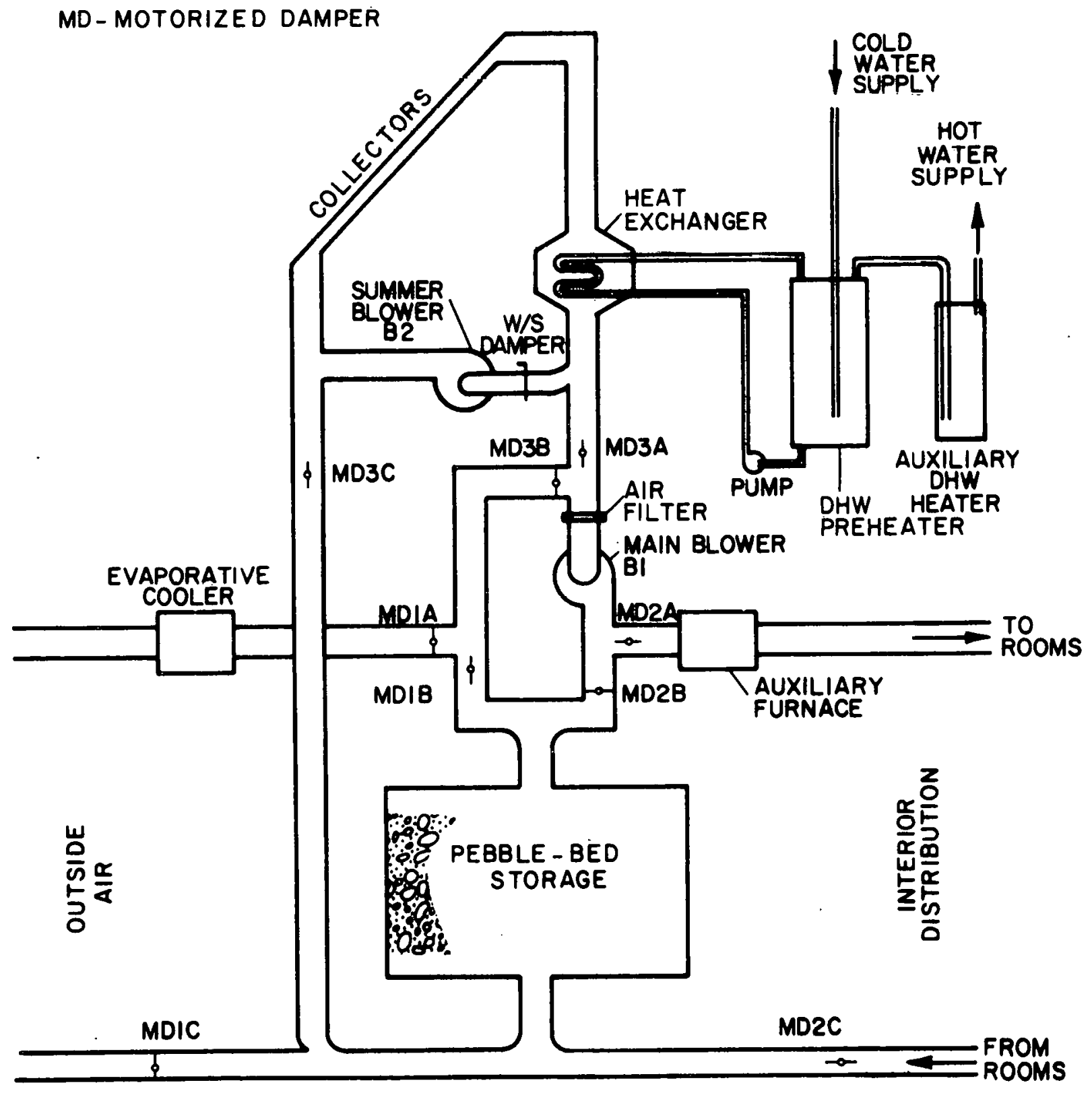

Figure 2. Schematic of the Air Solar System in Solar House II 
Table 1. Thermal Performance Data for Solar House I

Site-Built Flat Plate Collectors (SBFP)

Evacuated Tube Collectors (STFP)

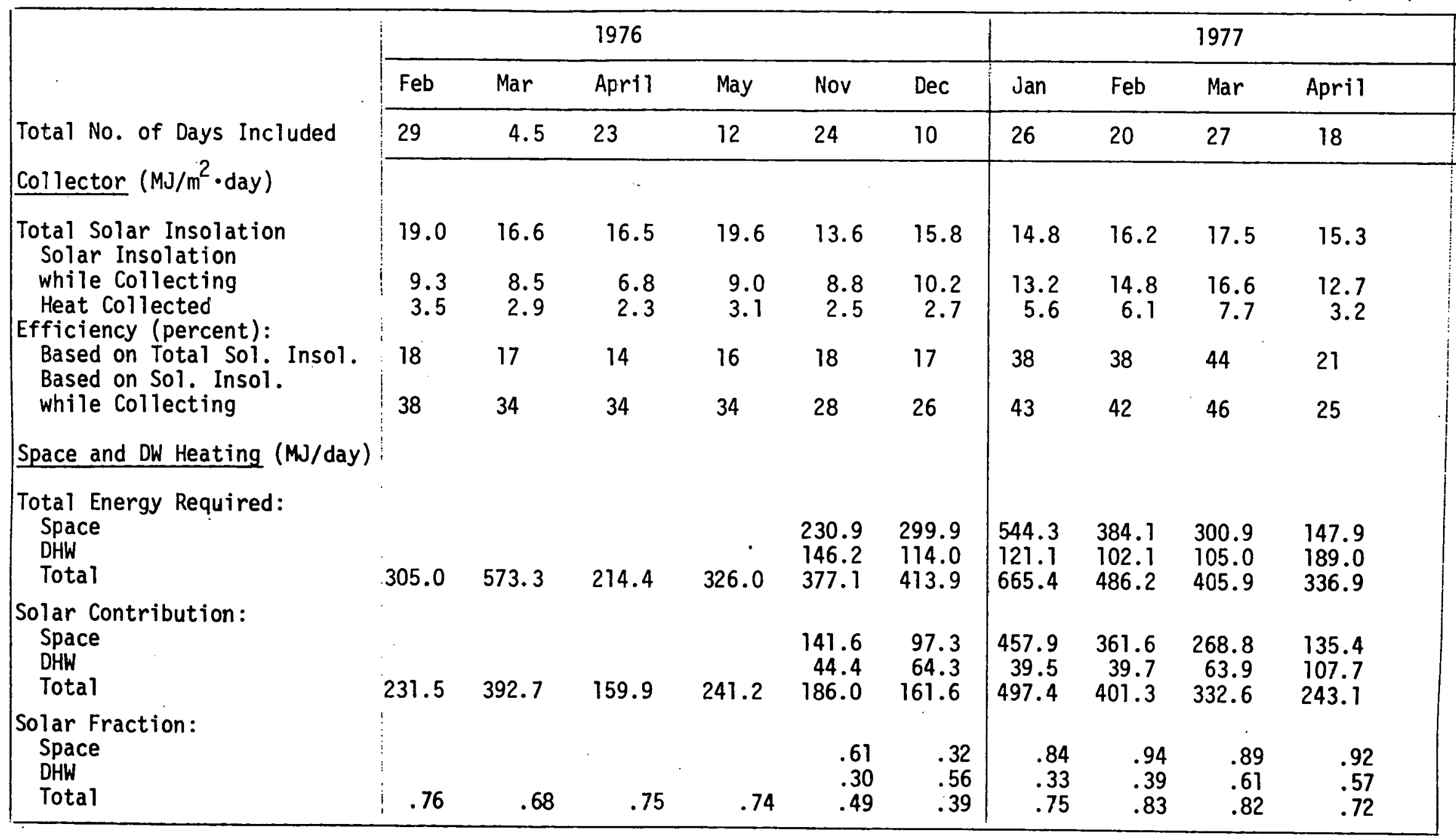


missing from the performance records because of instrumentation difficulties, a) though the system operated continuously during the period. The data in Table 1 also include the evacuated tube flat-plate (ETFP) system performance from 3 January through 25 Apri1 1977.

Performance data for the site-built flat-plate air-heating system (SBFP) in Solar House II are presented in Table 2 for the same days as in Table 1 with the exception of March 1976. With only 4.5 days of data for Solar House I in March, a meaningful comparison cannot be made for that month. The data in Table 2 are for all of March 1976.

\section{COLLECTORS}

Comparisons of the performance of the collectors functioning with the systems are shown in Figure 3. The energy rates are shown vertically against months along the horizontal axis. The bars on the left, for each month, are for Solar House I and the bars on the right for each month are for Solar House II. The liquid and air flat plate collectors are compared through December 1976, and the evacuated tube flat plate liquid heating collectors are compared with the air-heating flat plate collectors in 1977.

It will be noted that the solar insolation differs for the two houses. Separate Eppley model 8-48 pyranometers were used in a tilted orientation. The largest difference is 13 percent in May 1976. The flat plate air system operated over a longer period of the day, on average, than the flat-plate liquid system. The principal reason for the longer operating period during a day, hence for the heating season, is stratification of heat in the pebble-bed storage, as opposed to a non-stratified water storage tank in the liquid system. Because the air delivered to the 
Table 2. Thermal Performance Data for Solar House II

Site-Built Flat Plate Collectors (SBFP)

\begin{tabular}{|c|c|c|c|c|c|c|c|c|c|c|}
\hline \multirow{4}{*}{$\begin{array}{l}\text { Total No. of Days Included } \\
\text { Collector }\left(\mathrm{MJ} / \mathrm{m}^{2} \cdot \text { day }\right)\end{array}$} & \multicolumn{6}{|c|}{1976} & \multicolumn{4}{|c|}{1977} \\
\hline & Feb & Mar & April & May & Nov & Dec & Jan & Feb & Mar & April \\
\hline & 29 & 31 & 23 & 12 & 24 & 10 & 26 & 20 & 27 & 18 \\
\hline & & & & & : & & & & & \\
\hline $\begin{array}{l}\text { Total Solar Insolation } \\
\text { Solar Insolation }\end{array}$ & 18.7 & 22.1 & 14.8 & 17.4 & 13.5 & 15.8 & 15.1 & 15.6 & 17.7 & 14.2 \\
\hline $\begin{array}{l}\text { while Collecting } \\
\text { Heat Collected } \\
\text { Efficiency (percent): }\end{array}$ & $\begin{array}{r}14.9 \\
5.4\end{array}$ & $\begin{array}{r}17.2 \\
6.4\end{array}$ & $\begin{array}{r}10.3 \\
2.8\end{array}$ & $\begin{array}{r}12.2 \\
3.6\end{array}$ & $\begin{array}{r}11.2 \\
3.1\end{array}$ & $\begin{array}{r}13.8 \\
4.9\end{array}$ & $\begin{array}{r}12.9 \\
4.6\end{array}$ & $\begin{array}{r}13.6 \\
4.7\end{array}$ & $\begin{array}{r}15.6 \\
5.0\end{array}$ & $\begin{array}{r}12.2 \\
3.7\end{array}$ \\
\hline $\begin{array}{l}\text { Based on Total Sol. Insol. } \\
\text { Based on Sol. Insol. }\end{array}$ & 29 & 29 & 19 & 21 & 23 & 31 & 30 & 30 & 28 & 26 \\
\hline & 36 & 37 & 27 & 30 & 28 & 36 & 36 & 35 & 32 & 30 \\
\hline Space and DW Heating (MJ/day) & & & & & & & & & & \\
\hline $\begin{array}{l}\text { Total Energy Required: } \\
\text { Space } \\
\text { DHW } \\
\text { Total }\end{array}$ & 558.7 & 578.7 & 263.3 & 195.2 & $\begin{array}{r}311.6 \\
40.6 \\
352.2\end{array}$ & $\begin{array}{r}323.2 \\
52.3 \\
375.5\end{array}$ & $\begin{array}{r}432.9 \\
73.0 \\
505.9\end{array}$ & $\begin{array}{r}379.9 \\
82.9 \\
402.8\end{array}$ & $\begin{array}{r}319.0 \\
75.4 \\
394.4\end{array}$ & $\begin{array}{r}192.3 \\
62.8 \\
255.1\end{array}$ \\
\hline $\begin{array}{l}\text { Solar Contribution: } \\
\text { Space } \\
\text { DHW } \\
\text { Total }\end{array}$ & 357.4 & 404.2 & 188.1 & 155.9 & $\begin{array}{r}198.7 \\
21.3 \\
220.0\end{array}$ & $\begin{array}{r}257.5 \\
30.8 \\
288.5\end{array}$ & $\begin{array}{r}231.4 \\
63.5 \\
294.9\end{array}$ & $\begin{array}{r}239.6 \\
75.4 \\
375.0\end{array}$ & $\begin{array}{r}245.8 \\
67.4 \\
373.2\end{array}$ & $\begin{array}{r}166.1 \\
51.8 \\
217.9\end{array}$ \\
\hline $\begin{array}{l}\text { Solar Fraction: } \\
\text { Space } \\
\text { DHW } \\
\text { Total }\end{array}$ & .64 & .70 & .71 & .80 & $\begin{array}{l}.64 \\
.52 \\
.62\end{array}$ & $\begin{array}{l}.80 \\
.59 \\
.77\end{array}$ & $\begin{array}{l}.53 \\
.87 \\
.58\end{array}$ & $\begin{array}{l}.75 \\
.91 \\
.78\end{array}$ & $\begin{array}{l}.77 \\
.89 \\
.79\end{array}$ & $\begin{array}{l}.86 \\
.82 \\
.85\end{array}$ \\
\hline
\end{tabular}




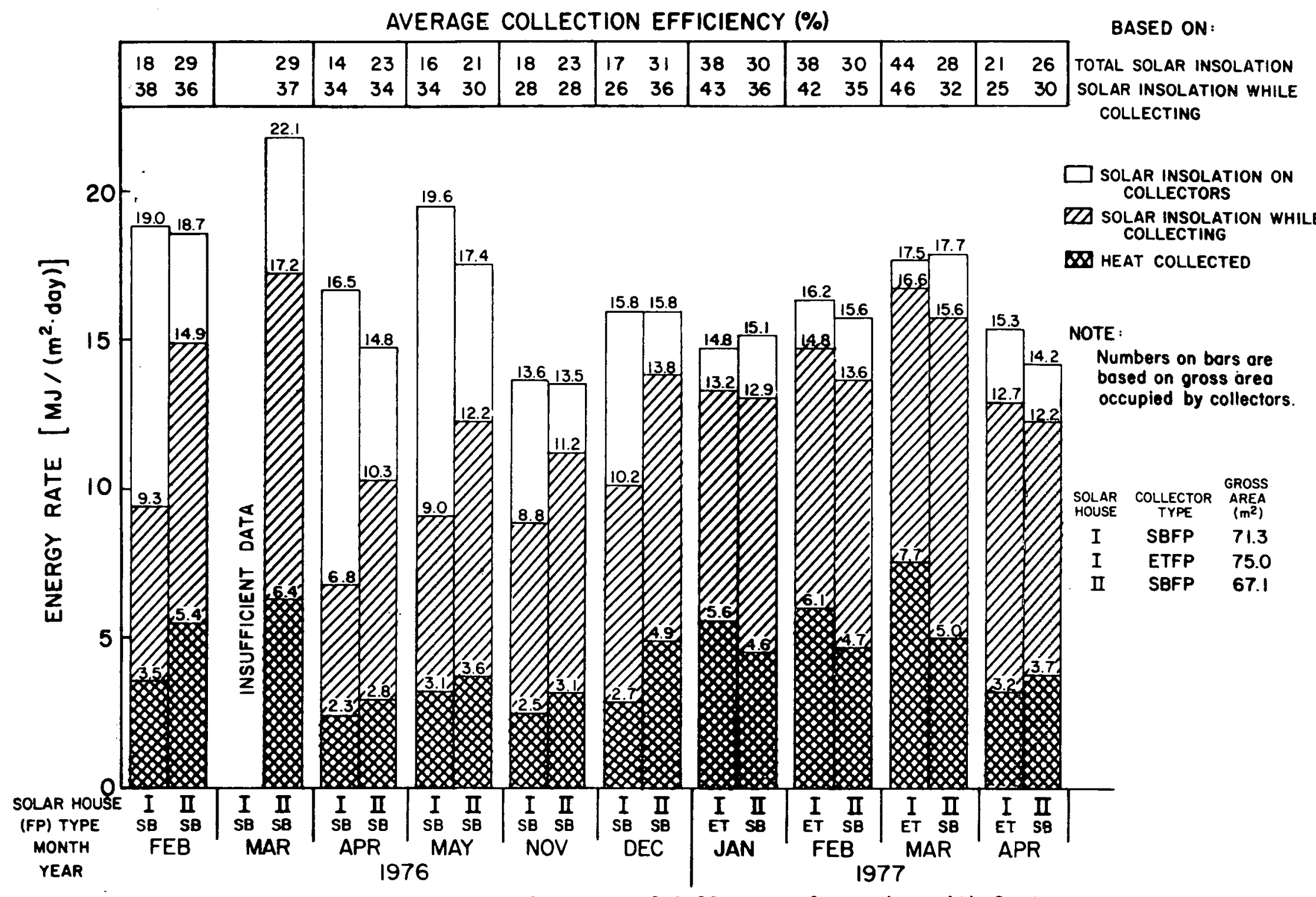

Figure 3. Comparative Performance of Collectors Operating with Systems (Based on same days) 
collector in the morning is always at room temperature (in winter) collection of heat begins earlier in the morning for the air system than the flat-plate liquid system. In the liquid system the storage tank temperature is $10-50^{\circ} \mathrm{C}$ greater than room temperature and collector start-up is delayed until the collectors are heated from $10-12^{\circ} \mathrm{C}$ above the storage tank temperature. In the afternoon, the liquid system stops earlier in time than the air system because the water temperature in storage increases gradually to a maximum and when the collector can no longer supply heat at a temperature greater than the storage tank temperature, the system will stop collecting. In an air system, as long as the air temperature from the collector is greater than the air temperature at the bottom of the pebble-bed storage which is near room temperature for much of the heating season, the system will continue to collect useful heat.

The evacuated tube collectors on Solar House I, have a significantly greater efficiency when compared to the flat plate collectors. The evacuated tube collectors have a selective absorber coating, while the double glazed flat plate collectors have flat black absorber coatings. Because of reduced heat losses the evacuated tube collectors are expected to operate over a longer period for any given day. On average, the evacuated tube collectors on Solar House I operated and converted 89.5 percent of the total measured solar radiation while the flat plate air collectors operated and converted 86.5 percent during a comparable period.

The monthly average dafly useful heat delivered per unit area (gross area) from each system is given in numbers above the double cross-hatched areas in Figure 3. For every month compared; the air-heating collectors 
delivered more heat than the flat-plate liquid heating collectors. Over the months of comparison, 40 percent more heat was delivered by the air collectors. The evacuated tube collectors delivered 27 percent more heat than the air collectors and is expected to deliver about 65 percent more than the flat plate liquid collectors on Solar House I, although a direct comparison was not made for the same period of operation.

\section{SPACE AND DOMESTIC WATER HEATING}

A comparison of system performance in terms of the fraction of solar energy provided for space and domestic water heating is shown in Figure 4. In comparing the two flat-plate systems, the air system provided a greater portion of heating and domestic hot water needs during the heating months in 1976. The solar fraction of the total $\mathrm{DHW}$ and space heating load was 0.69 with the air system and 0.60 for the liquid system (excluding March 1976 for both systems). The total load in Solar House II was 7 percent greater than in House I for the months compared. The solar fraction of the total load provided by the evacuated tube system was 0.78 from January through April 1977 and 0.77 for the air system with a 28 percent greater load in Solar House I as compared to House II.

While a separation of space and domestic water heating is not possible for the months of February through April 1976, it is instructive to compare the solar contributions to space and DHW for the balance of the comparison period. The solar contributions to space heating are shown in Figure 5 and to DHW load in Figure 6 . The total space heating load in House II was essentially the same as in House I from November 1976 through April 1977. The flat plate liquid system provided 45 percent of the space heating load in November and December and the evacuated tube system provided 89 percent from January through April. In comparable 


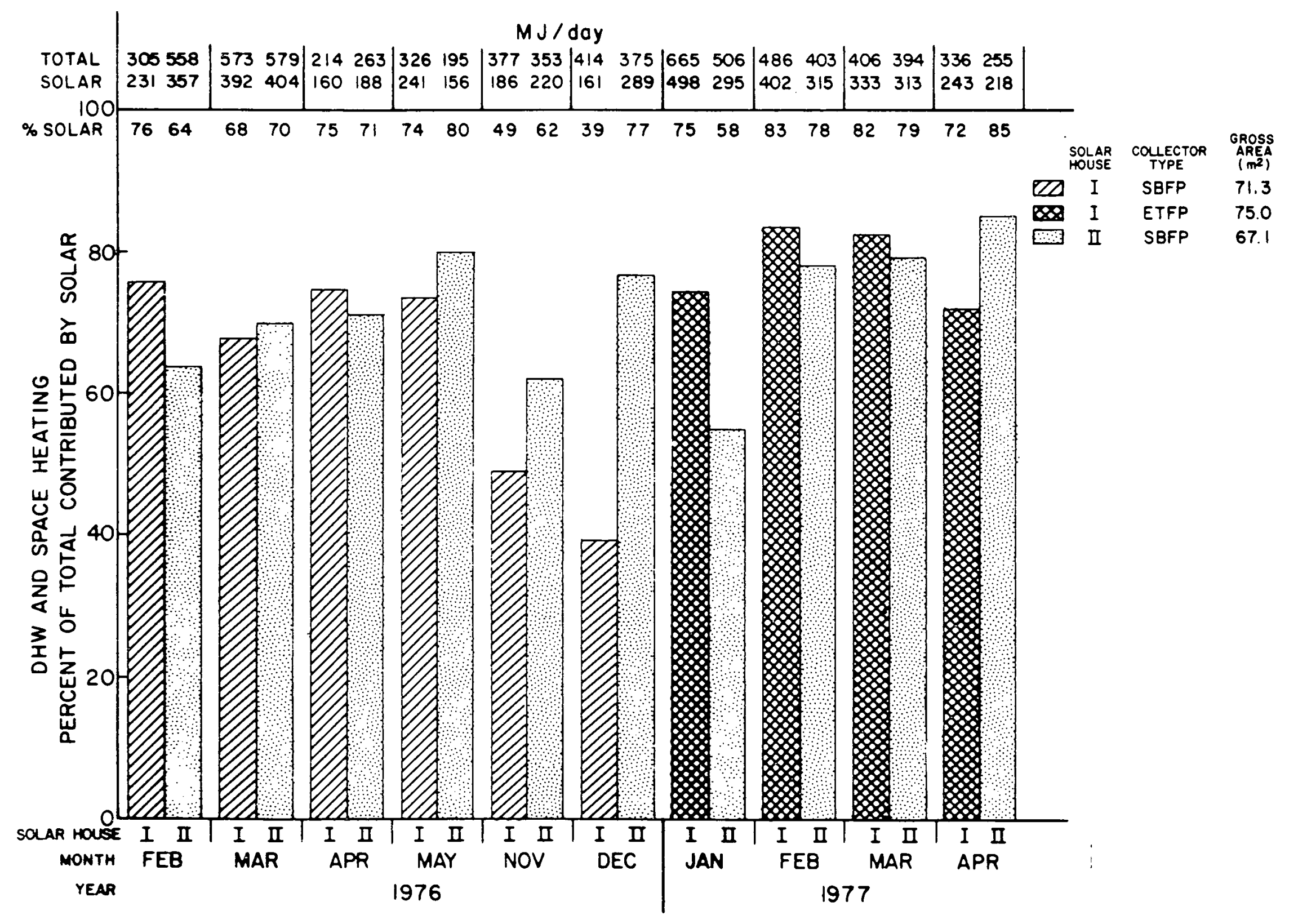

Figure 4. Comparison of Solar Contributions to Total Load (Based on same days) 


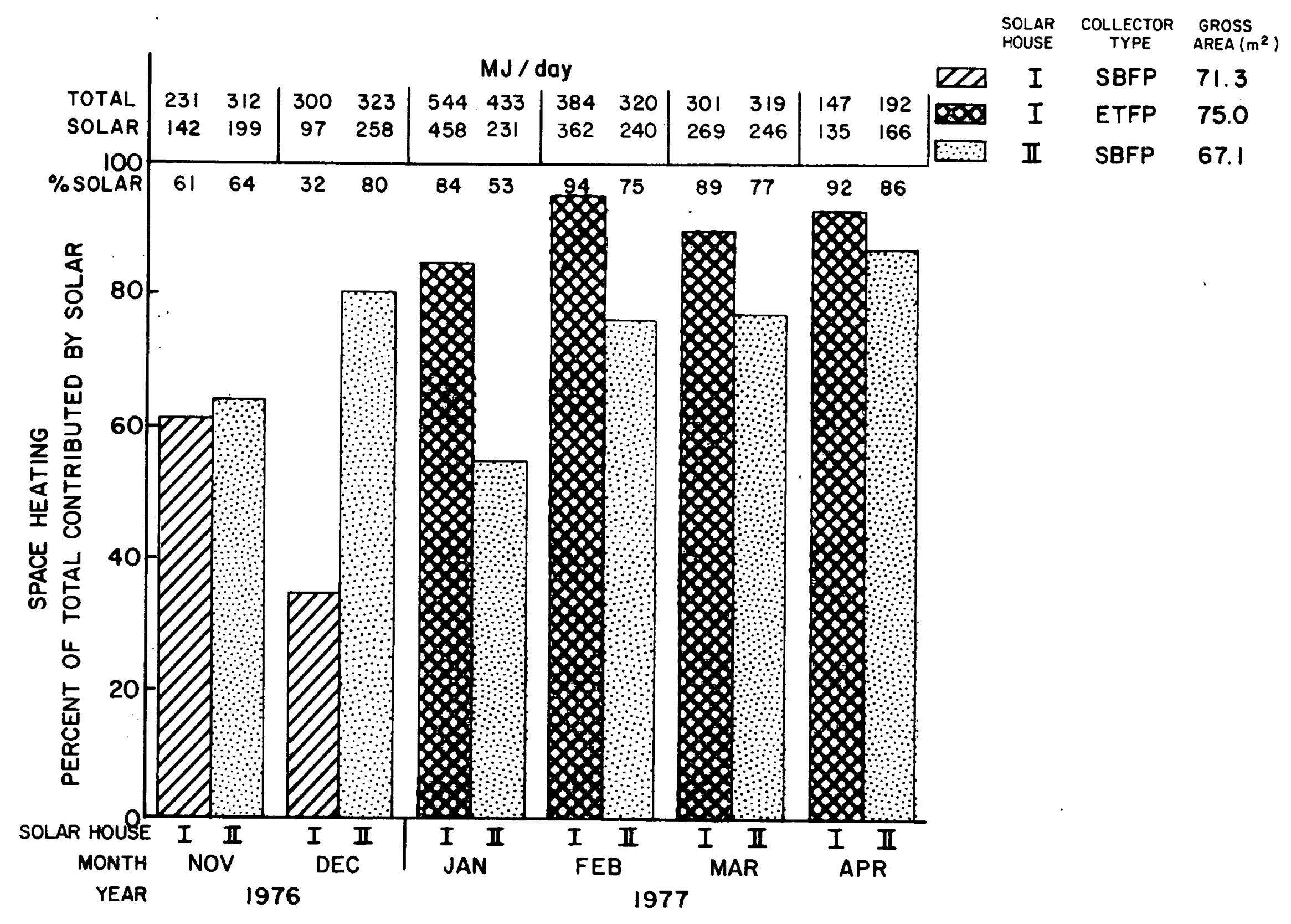

Figure 5. Comparison of Solar Contributions to Space Heating Load (Based on same days) 


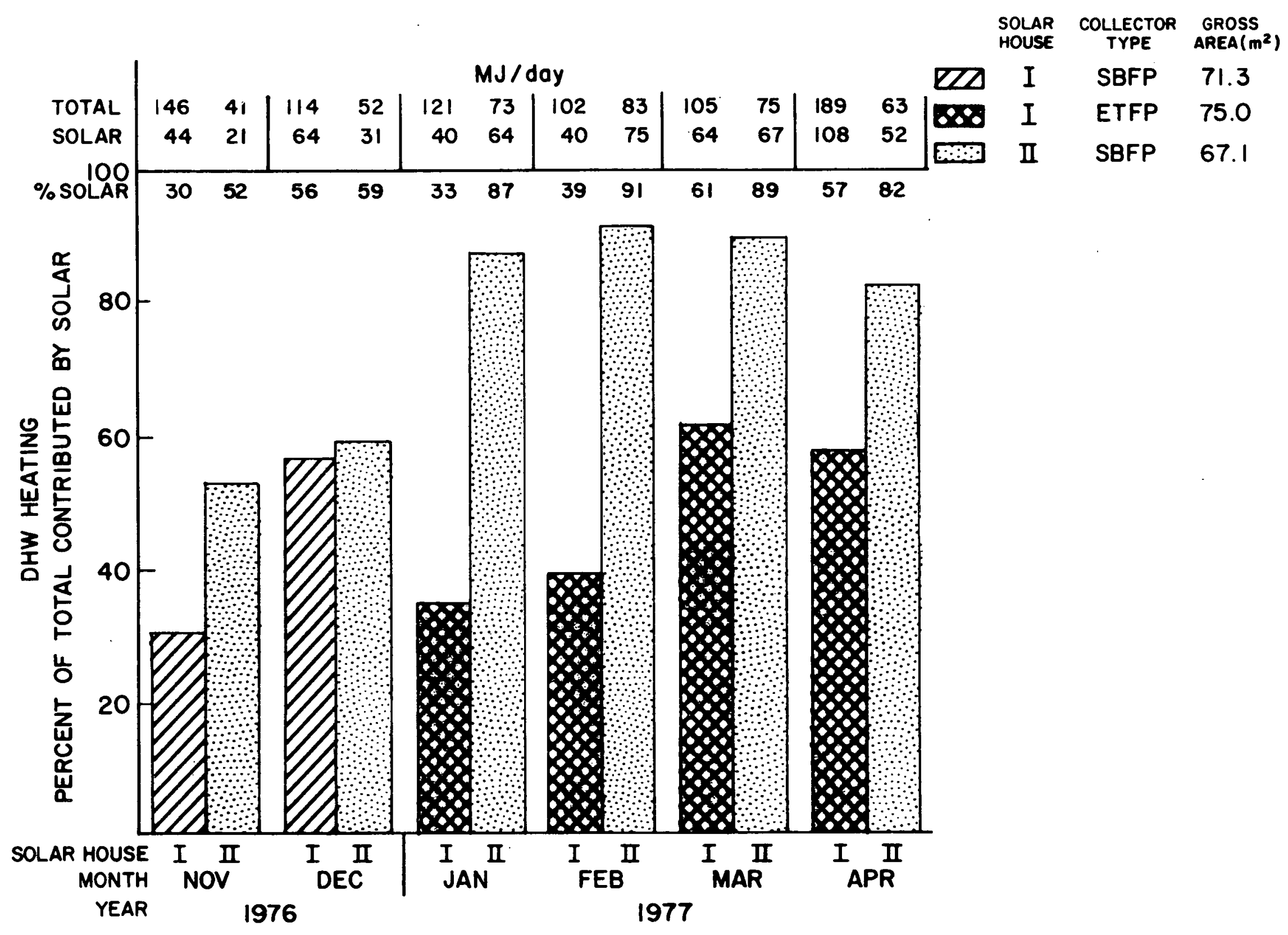

Figure 6. Comparison of Solar Contributions to DHW Load (Based on same days) 
periods, the air system provided 72 and 70 percent respectively. Over the total period, the liquid system provided 77 percent and the air system 71 percent of the space heating load.

The domestic water heating load (see Figure 6) in House I was double that in House II. The liquid solar systems provided 46 percent of the DHW load and the air system provided 80 percenl. Both systems have a 300-liter (80-gallon) preheater tank and it is worth nuling that the solar systems operated comparably in that preheating was provided only when the collectors were operating. Approximately 265 liters (70 gallons) of hot water is dumped daily from both systems. The difference in total load arises from the use of showers, dishwasher and a clothes washer in Solar House I, whereas there are no comparable facilities or appliances in Solar House II.

\section{CONCLUSIONS}

The flat-plate liquid and air systems on CSU Solar Houses I and II have been compared for specific periods during the 1975-1976 and 1976-1977 heating seasons. Overall, the flat-plate air heating system provided 40 percent more solar energy for space and domestic water heating based on gross unit collector area than a comparable flat-plate liquid-heating system and the evacuated tube liquid heating system provided 27 percent more heating from solar energy than the flat-plate air system. Both the liquid and air flat plate collectors had comparable flat black absorbers, while the evacuated tube absorber was selectively coated.

The air system operated over a longer period of the day than the flat-plate liquid system. In the comparison months in 1976, the air system operated for 78 percent of the total measured solar radiation while the liquid system collected heat during 52 percent of the measured solar 
radiation periods. From January through Aprif 1977 the evacuated tube collector system operated for 89.5 percent of total measured radiation, and the air system operated 86.5 percent. The collection efficiencies of the two flat-plate collectors are comparable based on operating time, and the evacuated tube system has an average collection efficiency of about 40 percent based on operating time, and gross area, while the flat-plate air system has an average daily efficiency of 33 percent on the same basis and for a comparable period.

\section{ACKNOWLEDGMENTS}

The on going studies of Solar Houses I and II are financially supported by the U.S. Department of Energy (DOE), the Sheet Metal and Air Conditioning Contractors' National Association, Inc. (SMACNA), and the National Training Fund (NTF) of the sheet metal industry and Colorado State University. The authors express their appreciation to Peter Armstrong, Michael Walker, Robert Pratt and Cecile Lebouf for their assistance in compiling the data.

\section{REFERENCES}

1. Ward, D.S., Weiss, T.A., and Löf, G.0.G., (1976). "Preliminary Performance of CSU Solar House I Heating and Cooling System". Solar Energy, Vol. 18, No. 6, pp. 541-548.

2. Ward, D.S., and Löf, G.0.G., (1976). "Design, Construction, and Testing of a Residential Solar Heating Cooling System". A report prepared for NATO Committee on the Challenges of Modern Society (CCMS) Solar Energy Pilot Study (data for September 1974 through August 1975). Also CCMS Report No. CO0/2755-76/1. Solar Energy Applications Laboratory, Colorado State Untversity, Fort Collins, Colorado. 
3. Ward, D.S., Löf, G.O.G., Smith, C.C., and Shaw, L.L., (1977).

"Design of a Solar Heating and Cooling System for CSU Solar House II". Solar Energy, Vol. 19, No. 1, pp. 79-85.

4. Karaki, S., Armstrong, P.A., and Bechtel, T., (1977). "Evaluation of a Residential Solar Air Heating and Nocturnal Cooling System". A report prepared for the U.S. Department of Energy and the National Training Fund of the Sheet Metal Industry, Washington, D.C. in a special CCMS format. Report No. CO0-2868-3. Solar Energy Applications Laboratory, Colorado State University, Fort Collins, Colorado. 